\title{
RESEARCHER-PERFORMER RELATIONS IN \\ CROSS-CRAFTING RITUALS IN LITHUANIA
}

\section{SKAIDRE URBONIENE}

The article ${ }^{1}$ presents the relationship between researchers and performers (woodcarvers) from the nineteenth century to the present in Lithuania. It discusses the role of the researcher in a woodcarver's creative work when creating a cross as his own. It examines what kind of help the carver expects from the researcher and what actual help is provided. The researcher's requirements from the master that can be observed during the cross-making process are highlighted, as are indirect performer-researcher relations when the performer himself studies ethnographic and iconographic material. Keywords: researcher, woodcarver, blacksmith, crosscrafting, devotional monuments
Članek obravnava razmerje med raziskovalci in ustvarjalci (rezbarji) v Litvi od 19. stoletja do danes. Avtorica razpravlja o vlogi raziskovalca in mojstra $v$ kreativnem procesu rezljanja križa ter o tem, kakšno pomoč od raziskovalca pričakuje rezbar. Raziskovalčeve zabteve do mojstra je moč opazovati skozi proces rezljanja križa; posredne odnose med ustvarjalcem ter raziskovalcem pa $v$ primeru, da se rezbar sam loti studija etnografskega in ikonografskega materiala.

Ključne besede: raziskovalec, rezbar, kovač, rezljanje križa, votivni spomeniki

\section{INTRODUCTION}

"Cross-crafting" refers to the widespread tradition of creating devotional monuments of small-scale architecture (such as crosses, roofed poles, poles with shrines, roadside chapels, and miniature shrines on trees), sculptures of saints and iron cross tops, the entire process of making them, and certain associated rituals (including consecration, decoration with plants, offerings, praying by the cross, meetings held by the monument, and so on).

Cross-crafting, a unique branch of Lithuanian folk art, was inscribed on the UNESCO Representative List of the Intangible Heritage of Humanity in 2001. ${ }^{2}$ Crosses were, and still are, built as memorials to the dead or as signs of spiritual protection, or erected at certain places to plead for grace or to express gratitude. Traditional Lithuanian devotional monuments combine elements of architecture, sculpture, blacksmithing, and sometimes even primitive painting. (UNESCO 2001)

1 The article was prepared with the support of a postdoctoral fellowship. The fellowship was funded by the European Union Structural Funds project "Postdoctoral Fellowship Implementation in Lithuania" within the framework of the Measure for Enhancing Mobility of Scholars and Other Researchers and the Promotion of Student Research (VP1-3.1-ŠMM-01) of the Program of Human Resources Development Action Plan.

2 Formerly the List of Masterpieces of the Oral and Intangible Heritage of Humanity. 
Crosses and other devotional monuments were erected in large numbers at farmsteads, in villages and townships, within cemeteries and churchyards, along roadsides and crossroads, and by rivers, lakes, and areas renowned for miracles. The range of intentions of monument building was very broad: from individual wishes, pleas, and facts of life to commemorative dates in the life of the community or nation, and for special occasions such as natural calamities, epidemics, and war.

Even when cross-building was prohibited or restricted by the occupants, the Russian Empire (the second half of the 20th century) and the Soviet Union (in the 1940s through to the 1970s), crosses were nevertheless being tenaciously erected all over Lithuania. (UNESCO 2001)

The Soviet period was characterized by the planned large-scale destruction of devotional monuments and a prohibition on building new ones or repairing old ones. Only the most artistically designed objects, which monument-preservation specialists managed to include on the list of protected cultural monuments, were left untouched. However, despite the restrictions, the cross-crafting tradition also lasted through the Soviet period. People mostly built monuments on their farmsteads or in remote places where the local authorities rarely came. Of course, during that period the extent of cross-crafting was very limited in comparison with previous times. Now, after the restoration of independence (in 1990), an abundance of newly built crosses and other types of monuments all over Lithuania is evident.

This article presents the relationship between researchers and performers (woodcarvers) from a historical perspective and focuses on issues of safeguarding the contemporary living cross-crafting tradition. In the case of the cross-crafting ritual, which consists of several stages, I focus on the initial stages; that is, making the monument. In this phase, woodcarvers or craftsmen act as performers.

In Lithuanian historiography, proper attention has not yet been dedicated to the relationship between the creator/performer and researcher. A few references should be noted. In a book based on her dissertation, the ethnologist Aušra Zabielienè deals with folkdance ensembles in Lithuania. In one chapter devoted to the clothing of the ensemble members, the author discusses folk costume researchers' impact on the picturesque clothing of the ensembles (2010: 116-140). The brief mention of the relationship between woodcarvers and researchers is traced in the article on making copies by Alè Počiulpaitè (2008: 172-192). Some indirect relations are also mentioned in published interviews with woodcarvers (Tumenas 2009: 42-59). Therefore, this article is the first attempt to examine the crosscrafting process from the perspective of relations between the researcher and the woodcarver.

The research was carried out on based on published and archival material referring to the performer-researcher relationship from a historical perspective. The research on the contemporary situation is based on the author's own experience while working at the National Museum of Lithuania (until 2010) and on fieldwork in 2011. During fieldwork in various districts of Lithuania, twenty woodcarvers were interviewed about their creative 
work; questions about their relationship with researchers (museum workers, art historians, and ethnologists) were also asked.

\section{RESEARCHERS AND WOODCARVERS IN THE NINETEENTH CENTURY AND FIRST HALF OF THE TWENTIETH CENTURY}

The tradition of building devotional monuments is rather old in Lithuania, dating back to the sixteenth century, but researchers became interested in cross-crafting rather late. The first observations about wooden devotional monuments appeared in the mid-nineteenth century (Gadon 1846; Jucewicz 1839, 1840, 1842, 1846; Połujański 1859; Römer 1860). Real research work on this phenomenon can be seen at the very beginning of the twentieth century. Throughout the twentieth century, wooden monuments and religious sculptures were generally the most popular themes for Lithuanian scholars and local ethnographers.

The nineteenth century and first half of the twentieth century was the time when cross-crafting was studied in detail and valuable material on this phenomenon was accumulated. During this period, attention was drawn to various forms of devotional monuments, their ornamentation, their decoration, and a main feature of monuments: sculptures of saints. Interest in this phenomenon was shown by Polish-speaking and foreign researchers-Michał Brensztejn (1906), Casimir de Danilowicz (1919), Bronisław GinetPiłsudzki (1916), Franciszek Krzywda-Polkowski (1909), Juzef Perkowski (1929a-b), and Wandalin Szukiewicz (1903)_ _ as well as Lithuanian scholars: Jonas Basanavičius (1912), Klemensas Čerbulènas (1938), Marijona Čilvinaitė (1938), Paulius Galaunè (1930, 1932), Antanas Rūkštelè (1929, 1931, 1941), Kazys Šimonis (1923a, b), Adomas Varnas (1925), and Mikalojus Vorobjovas (1939). At that time, museums began to accumulate collections of folk sculpture and iron cross tops as well as iconographic collections of photos and drawings. These collections reflect a variety of forms of wooden monuments and represent regional features as well. The earliest photos date from the beginning of the twentieth century. Three researchers that were also photographers and devoted their leisure time to recording crosses and other devotional monuments should be mentioned: the artist Varnas, and the local ethnographers Balys Buračas and Ignas Končius. They accumulated large collections of photographic material on cross-crafting. These historical photos depict old monuments built as far back as the nineteenth century and also show their surroundings, master craftsmen, and rituals - from the creation and installation processes to consecration and related traditions (decoration with plants and visits on various occasions). At present, these collections are distributed among several museums in Vilnius and Kaunas. ${ }^{3}$ This iconographic material offers unique material for researchers, and also for the performers (i.e., craftsmen) for their creative work.

3 National Museum of Lithuania, Mikalojus Konstantinas Čiurlionis National Art Museum, Vytautas the Great War Museum, and Lithuanian Art Museum. 
In general, in the nineteenth century and first half of the twentieth century, researchers only collected and documented the products of cross-crafting. The relationship between researchers and creators during this period could be described as one-sided. Woodcarvers (in Lithuanian, literally 'god-makers') and cross-makers did not expect any real help from the researcher, and, in fact, they did not need it. At that time, the researcher-performer relations were limited to recording the carvers' biographies and photographing them. The majority of these biographies were written by the local ethnographer Buračas and the artists Vytautas Bičiūnas and Kazys Šimonis. Several master craftsmen's biographies were published in periodicals in the 1920s, 1930s, and 1940s (Bičiūnas 1928, 1929; Buračas 1939a-d, 1942, 1944; Šimonis 1923b).

However, properly speaking, the weak direct relations between the researcher and performer in the cross-crafting process can already be seen in the first half of the twentieth century.

In 1928, the War Museum in Kaunas (now named the Vytautas Great War Museum) launched a campaign to encourage people to build crosses and other devotional monuments for the tenth anniversary of Lithuania's independence. For this purpose, the artist Varnas created thirty-six projects involving crosses and other monuments. He created these projects based on his rich photo collection on cross-crafting (consisting of more than 2,000 photos and negatives). Varnas carefully studied his collection, selected typical

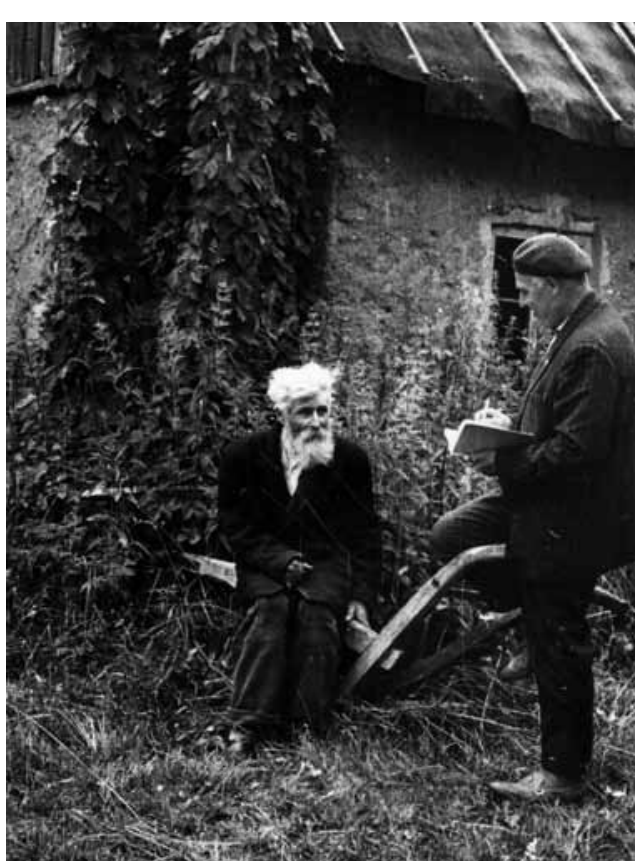

Figure 1. Ethnographer Juozas Petrulis' interview with cross-maker Jonas Remeika in 1959, Trivalakiai village, Pakruojis district (The National Museum of Lithuania). examples of the devotional monuments of certain areas, and based on this he created generalized monuments for several districts of Lithuania. These projects were distributed throughout the country by the War Museum. Based on these projects, many devotional monuments were built (some of them are preserved to this day).

The master craftsmen that were commissioned to make monuments for Varnas' project worked on them very accurately. The photos of these completed monuments show that the carvers executed the objects precisely according to the dimensions shown in the project; they carved exact decorative details and sculptures, made exact representations of the iron tops, and so on. In this case, the master craftsmen already used the investigative work of the researcher Varnas, and worked according to his requirements shown in the drawings. 
During Soviet times, the researcher-craftsman relationship was also one-sided. Woodcarvers of that time made crosses secretly due to prohibitions by the Soviet authorities. The researchers mostly documented tradition, questioned living old masters, and collected material, part of which was published. Mentioned should be made of the museum worker and ethnographer Juozas Petrulis and the art historian Zita Žemaitytè, who compiled many cross-crafters' biographies and published some of them in cultural journals of the Soviet period (Petrulis 1943, 1960, 1963, 1964a-b, 1965, 1968, 1986; Petrulis \& Žemaitytè 1966a-b, 1969, 1971; Žemaitytė 1970, 1981). The greatest work was done by Petrulis (Figure 1), who collected the biographies about seventy craftsmen (living at that time or already deceased). His material and photos are kept in the Rare Book and Manuscript Department of the Martynas Mažvydas National Library of Lithuania in Vilnius and often are used for research by ethnologists and art historians.

\section{RESEARCHERS AND WOODCARVERS IN THE PRESENT}

It is possible to speak about a direct relationship between researchers and woodcarvers only from the beginning of the twenty-first century; that is, since 2001, when cross-crafting was included on the UNESCO Representative List of Intangible Heritage. What has changed in this period?

Primarily, in comparison with Soviet times, more active research on the phenomenon is noticeable. The research work has been carried out not only in museums, but at academic institutions as well. These research institutions have organized three conferences on cross-crafting, ${ }^{4}$ and two dissertations have been defended on this topic (Urboniene 2009; Zabulytė 2007). Numerous articles are regularly published in popular and academic journals. National and regional museums have set up exhibitions of the phenomenon, and temporary exhibitions on the subject are also held almost every year. Through conferences, publications, catalogues, and exhibitions, researchers disseminate knowledge about the cross-crafting tradition, they introduce this tradition to the younger generation, and at the same time they provide valuable information to the creators of this tradition: modern cross-makers and woodcarvers.

Workshops and lectures for master craftsmen are also held throughout the country in order to safeguard this tradition. This work with woodcarvers is mainly carried out by specialists from the Lithuanian Folk Culture Center and the Lithuanian Folk Art Society. They themselves, or invited researchers from academic institutes and museums, give talks

4 The conference Lithuanian Cross-Crafting, held by the National Museum of Lithuania and Lithuanian Catholic Academy of Science in 2002; the conference Lithuanian Crosses in a Worldwide Context, held by the Art Institute of Vytautas the Great University and the Lithuanian Artist Society in 2005; and the conference The Phenomenon of Cross-Crafting in Folk Culture, held by the Culture, Philosophy and Art Research Institute and Lithuanian Folk Culture Centre in 2006. 
for craftsmen, present archival material to them, and interpret the regional ethnographic characteristics of devotional monuments. Woodcarvers attend these seminars and talks in order to learn more about the characteristic features of monuments of certain areas. Educated customers (who often want to have a monument characteristic of where they live) and folk art competitions encourage them to create in line with tradition.

Mention should be made of the annual Golden Wreath competition, held by the Lithuanian Folk Culture Center since 2005. During this contest, the best folk artists in various folk art fields are awarded, including the best cross-maker. Another competition, the Best Blacksmith, is devoted to cross-making blacksmiths and has been held by the Lithuanian Folk Art Society since 2007. These are prestigious competitions and folk artists prepare for them seriously. First they have to go through the selection for the region where they live, and the best from the region attends the national competition, where an expert committee selects the winners.

These competitions have clear evaluation criteria: the master craftsman must demonstrate not only the artistry of his creative work and his technical skill, but his creative work must also correspond to traditional Lithuanian folk art and ethnic cultural traditions (Ašmonaitienè 2009: 5). One of the main goals of these contests-maintaining and refreshing vanishing folk art traditions - requires the creator to know the creative roots of the nation very well. One requirement is not to copy old monuments, but to develop the master craftsman's own style by seeking harmonization between tradition and innovation.

To enter these contests, artists must have a good understanding of local traditions. Therefore they attend seminars and study material themselves. During fieldwork, most of the master craftsmen said that they study albums from the Folk Art series and museum catalogues. Such material available in their libraries includes Lietuviu liaudies menas: Skulptūra (Lithuanian Folk Art. Sculpture; Galaunè 1963, 1965), Lietuviu liaudies menas: Mažoji architektūra (Lithuanian Folk Art. Small-Scale Architecture; Čerbulènas et al. 1970; Šešelgis 1990; Stravinskas \& Sakalauskas 1992), Lietuvių liaudies menas (Lithuanian Folk Art; Bernotienè et al. 1993), and issues of the journals Liaudies kultūra (Folk Culture; published by the Lithuanian Folk Culture Center) and Tautodailes metraštis (Folk Art Chronicle; published by the Lithuanian Folk Art Society).

Overall, a majority of Lithuanian museums present some aspects of the cross-crafting phenomenon in their permanent displays, mostly folk religious sculpture (Figure 2) and the iron tops of crosses. However, the exhibits represent only a small part of the traditional heritage. There are only a few examples of large-scale monuments such as crosses, poles with shrines, roofed poles, and chapels in the museum exhibits. I have noticed that the material on the cross-crafting tradition shown in Lithuanian museums dedicates too little attention to woodcarvers.

This is why woodcarvers often turn individually to researchers, usually museum specialists, for assistance. In most cases, this relationship is limited to an initial consultation, when a researcher selects particular items (exhibits or photos from a particular region or 


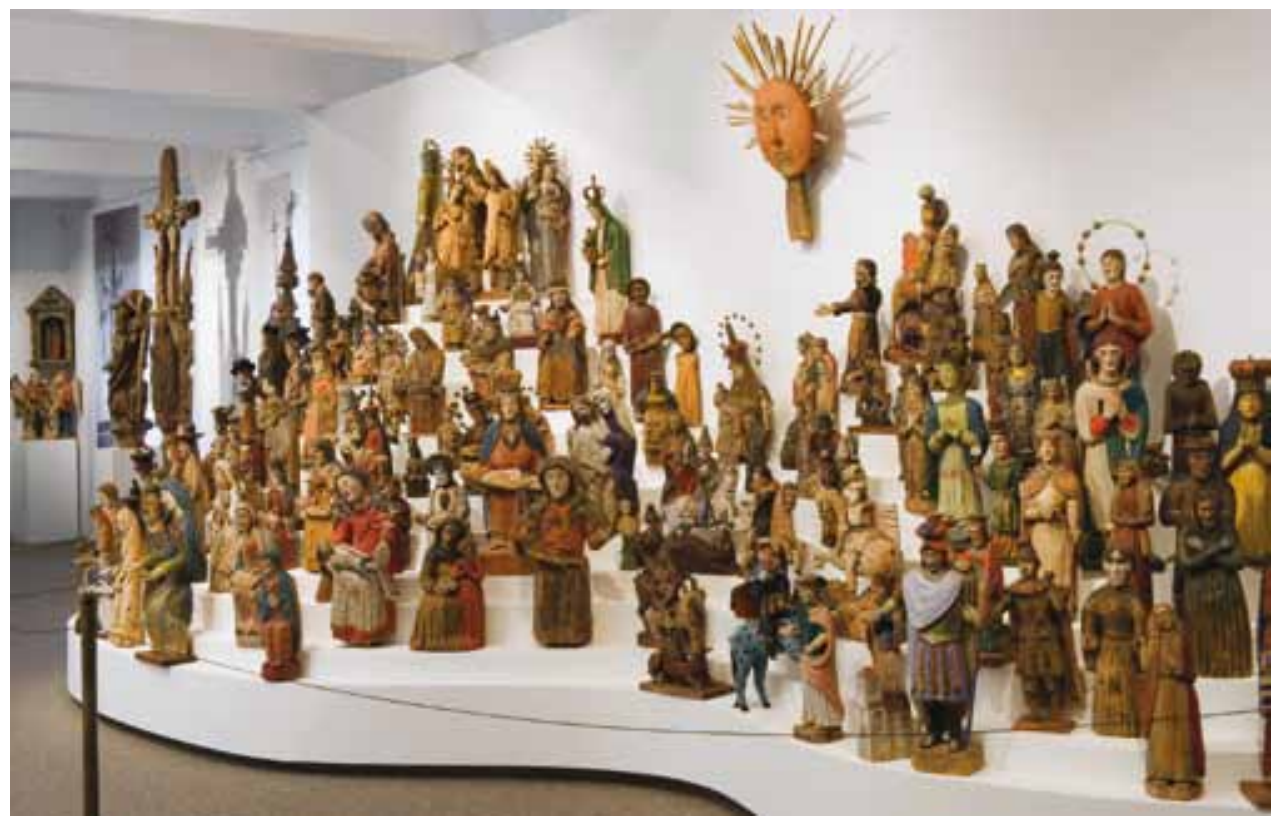

Figure 2. Cross-crafting display in the National Museum of Lithuania. (Photo: S. Urbonienė, 2009)

vicinity) at the master craftsman's request. When material is collected, the woodcarver works individually, no longer contacting the researcher, unless he invites a consulting researcher to participate in the monument installation and consecration rituals.

The following is one example from my experience. I regularly give consultations to the local woodcarver Adolfas Teresius (Figure 3). He is a well-known woodcarver that receives commissions from all over Lithuania. He not only studies literature, catalogues, and albums, but also collects material on cross-crafting (old sculptures and iron cross tops), and so he himself could be defined as a researcher. However, sometimes he needs specific information. A few years ago, he received an order to make a roofed pole with a sculpture of St. Apollonia. However, the carver did not know how this saint is depicted in traditional folk sculpture because he failed to find sculptures of her in published albums. I sent him material prepared for publication in my article discussing the iconography of women saints in traditional Lithuanian folk sculpture. ${ }^{5}$

In 2011, Teresius was commissioned to make roofed pole with a sculpture of St. Cecilia, the patron of music. St. Cecilia is an extremely rare image in Lithuanian folk sculpture, but there are a few examples in archival material that is unknown to cravers or difficult for them to access. So my article (already published) helped him again. After completing the monument, he invited me to participate in the events connected with installing and consecrating the monument. 


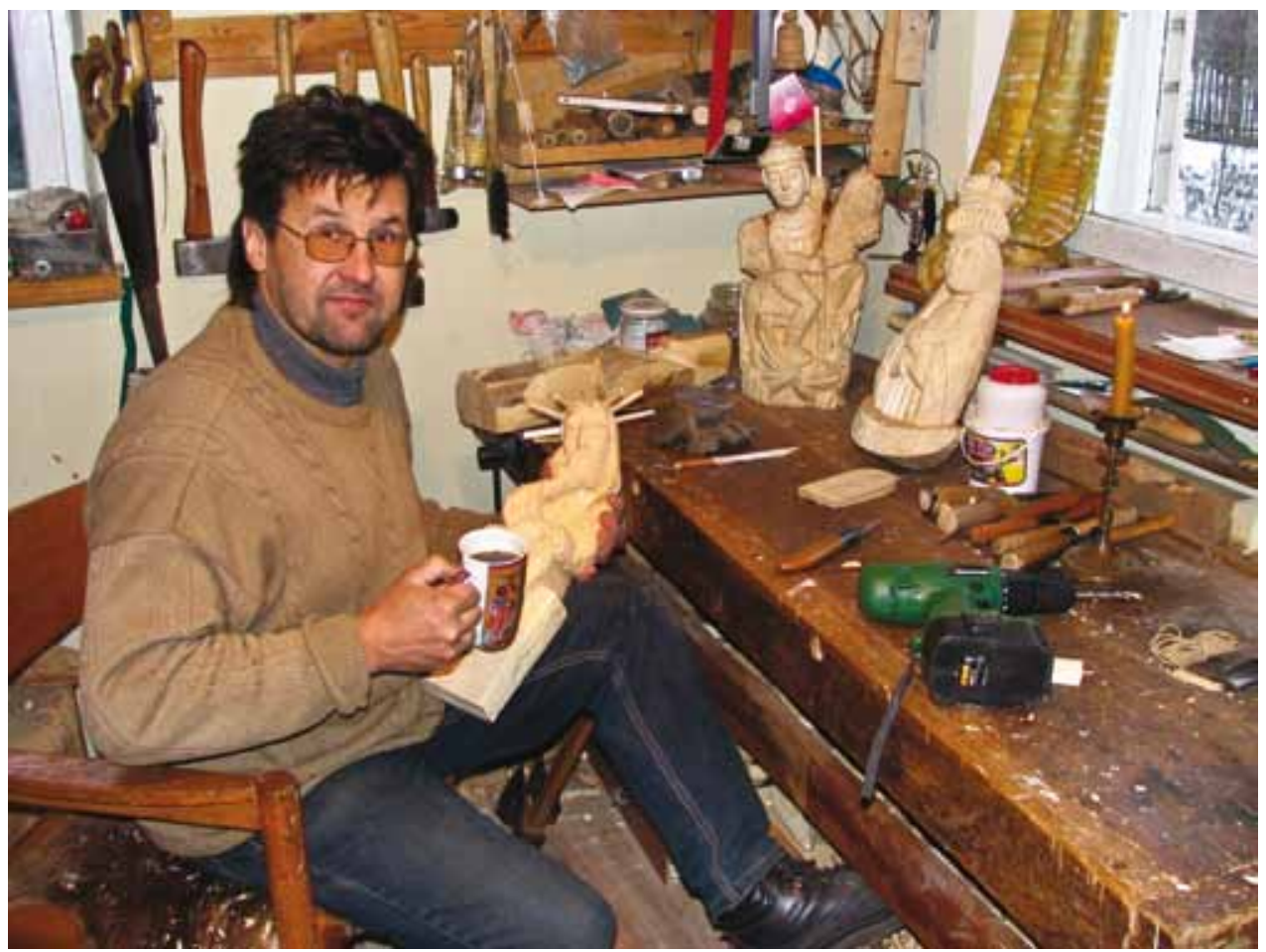

Figure 3. Woodcarver Adolfas Teresius in his workshop in Garliava town, Kaunas district. (Photo: S. Urbonienè, 2004)

Incidentally while setting up this monument, I was directly consulted as a researcher. The question arose which direction St. Cecilia's statuette should face. The local cultural society involved in setting up the monument wanted to turn the sculpture towards the village, but Teresius insisted on the statuette facing the road because it is the traditional way of placing statuettes in roadside monuments. And he was quite right. In traditional monuments the main holy images were placed on the most important side of the monument, and this side of a roadside monument is to face the road. So I had to intervene and support the carver's opinion, giving a brief introduction to the tradition of roadside monuments. This monument was built along a pilgrimage route to the famous Lithuanian shrine of Šiluva, and so pilgrims and other passersby going that way have to see the main iconographic feature of the monument: St. Cecilia.

A slightly different situation is noticeable with blacksmiths. Blacksmiths usually study ethnographic and iconographic material themselves without going directly to researchers. This is easier to do for them because almost all museums display metal crosses, and many museums have published catalogues of their collections on the metal cross-making tradition (Bernotaitė-Beliauskienè 2003; Kontrimas 1991; Kynas 2005; Laučkaitė-Surgailienè 2003; Miliauskienė 2005; Mockutė 2003; Petrulienė 2003; Šakienè 2008; Spudytė 2005; Urboniene 2002). Therefore, in this case, the blacksmiths have material collected and 
published by the researchers and thus the relationship between the blacksmith and researchers can be described as indirect.

As was shown above and through other examples from fieldwork, a creator that purposely studies traditional heritage (in museums or from specialized literature) becomes a special investigator, one that can both advise and consult his client, his apprentices, and his followers, or sometimes he may provide the researcher with certain valuable observations.

So far, I have focused on cases in which the carver is working on his own original project. However, carvers also make copies of old monuments. Copies are one conception of heritage protection. In Lithuania, copying devotional monuments began in the last decades of the twentieth century (Počiulpaite 2008: 177). The point of this method is to preserve the most valuable examples of surviving heritage by moving them to museums or other special places (churches or cemetery chapels) and placing an exact copy on the site. Copies preserve the function and meaning of the surroundings of the original monument.

Making copies is initiated by cultural institutions involved in heritage protection: museums and national or regional parks. These projects are sponsored by the local authorities, the Department of Cultural Heritage (under the Ministry of Culture), the Culture Support Foundation, and others. Making copies is based on comprehensive research and is supervised by researchers. The first step usually belongs to a researcher, who has to decide and select which monument is worth being copied. The researcher also gathers iconographic material to supplement details of selected monuments when they are in very poor condition. Sometimes a copy is made based solely on iconographic material if the original object has completely deteriorated. The second step is to find a woodcarver. This is also done by the researcher or by the local cultural institutions that commission the copy. When the master craftsman is found, he is provided with the material gathered by the researcher. Later his drawings are confirmed by specialists; the master craftsman is also monitored and consulted during the entire creative process. The last step-installing the copy-is also supervised by the researcher. In this case, the performer (the woodcarver) is passive, and the researcher is active throughout the creative process and even during the monument installation and consecration rituals.

\section{CONCLUSIONS}

In conclusion, it should be noted that today the creator always has a connection with the researcher in the cross-crafting process.

Making copies and original commissions should be distinguished. The researcher's role dominates in the process of making copies. In other cases (not copies), the role of the supervisor belongs to the woodcarver or performer, and the researcher has an advisory role. The most common indirect relationship between the performer and researcher is observed when the performer himself studies the researcher's work summarized in published material. 
The phenomenon when the creator of the monument himself acts as a researcher, gathering material about crosses or other types of monuments in a certain area, is observed as well.

The old master craftsmen of the first half of the twentieth century had no direct relations with researchers and did not seek them out. They themselves were experts in the tradition. It was the researchers that were looking for contacts with cross-carvers in order to learn about the cross-crafting tradition. After the Soviet era-when the tradition was suppressed and the old master craftsmen, the experts in the tradition, died out - the situation changed. Now the carvers need the knowledge that researchers can provide.

The new generation of master craftsmen does not know the tradition. The ancient cross-makers learned from one another, or a master craftsman passed the secrets of his trade to his son or grandson. Now there is no such continuity. Thus, the new woodcarvers, often young, require knowledge not only for the technology itself-which they learn at creative camps and craft schools-but also for knowledge of the cross-crafting tradition; in particular, forms of crosses and other monuments, special decorative features, sculptural themes, and especially regional characteristics, originality, and differences between monuments. During the last decade, the relationship between performers and researchers has strengthened, and these relations have become important for maintaining the vitality of the cross-crafting tradition in the present. At this point, however, a question could be posed: does the researcher's interference in the creative work of the woodcarver harm the natural vitality of tradition? There are two possible answers. On the one hand, masters have to know tradition quite well in order to safeguard the living tradition. For this reason they must have contact with researchers and follow their instructions. On the other hand, overly strict regulation of woodcarvers' work may suspend the natural development of tradition. The last remark on these two answers is that the role of the researcher in the contemporary living tradition process should be advisory and consulting, rather than prescriptive and commanding. Finally, it can be concluded that, in any case, safeguarding the living tradition of cross-crafting today is impossible without a relationship (direct or indirect) between performers (woodcarvers) and researchers.

\section{REFERENCES}

Ašmonaitienè, Laisvè (ed.)

2009 Respublikine konkursine liaudies meno paroda. Katalogas. Vilnius: Lietuvos liaudies kultūros centras.

Basanavičius, Jonas

1912 Lietuvių kryžiai archaiologijos šviesoje. In: Jaroševičius, Antanas (ed.), Lietuviu kryžiai: albumas. Vilnius: Lietuvių dailès draugija.

Bernotaité-Beliauskiené, Dalia (ed.)

2003 Lietuvos sakralinè daile XI-XX a. pradžia: Lietuviu liaudies menas. XVIII-XX a. T. 2. Vilnius: Lietuvos dailès muziejus. 
Bernotienè, Stasè et al. (eds.)

1993 Lietuviu liaudies menas. T. 1. Vilnius: Vaga.

Bičiūnas, Vytautas

1928 Dievadirbiai. Trimitas 28: 915-917.

1929 Mūsų „dievukai“ ir „dievdirbiai“. 7 meno dienos 44: 3-5; 45: 4-6.

Brensztejn, Michał

1906 Krzyźe i kapliczki Żmudzkie. Materyaty do sztuki ludowej na Litwie. Kraków: Nakładem Akademii Umiejętności.

Buračas, Balys

1939a Dievdirbys Jonas Orvidas. Naujoji Romuva 16: 353-355.

1939b Kražių dievdirbys Jūdpauparis. Sekmadienis 27: 3.

1939c Kryždirbys Vincas Svirskis. Naujoji Romuva 12: 281-283.

1939d Varnių dievdirbys Vaišnoris. Naujoji Romuva 23-24: 500-501.

1942 Žemaičiu dievdirbiai. Ükininko patarejas 22 (670): 6.

1944 Žemaičių dievdirbio trobelèj. Ateitis 68: 3.

Čerbulènas, Klemensas

1938 Mažosios Lietuvos antkapiniai paminklai. Naujoji Romuva 1-2: 42-44.

Čerbulènas, Klemensas et al. (eds.)

1970 Lietuviu liaudies menas. Mažoji architektūra. Kn. 1. Vilnius: Vaga.

Čilvinaite, Marijona

1938 Kam stato ir kaip brangina žmonès kryžius ir koplyčias. Gimtasai kraštas 3-4: 399-404.

Danilowicz, Casimir de

1919 La Lituanie Artistique. Lausanne: Bureau d'information de Lituanie.

Gadon, Michał

1846 Opisanie powiatu Telszewskiego w gubernji Kowieńskiej, w dawnem Xięstwie Żmujdzkiem potoźonego. Wilno: Ogiński.

Galaunè, Paulius

1930 Lietuviu liaudies menas. Kaunas: L. U. Humanitarinių mokslų fakultetas.

1932 Lietuvių liaudies skulptūros problemos. Vairas 2: 181-188; 3: 301-310; 4: 500-503; 5: 63-66; 6: $212-215$.

Galaune, Paulius (ed.)

1963 Lietuviu liaudies menas. Skulptūra. Kn. 1. Vilnius: Vaga.

1965 Lietuviu liaudies menas. Skulptūra. Kn. 2. Vilnius: Vaga.

Ginet-Piłsudzki, Bronisław

1916 Les croix Lithuaniennes. Bãle: Impr. G. Krebs.

Jucewicz, Ludwik Adam

1839 Rysy Żmudzi. Tygodnik Peterburski XIX: 27-29.

1840 Rysy Żmudzi. Warsawa: W drukarni Maxymiliana Chmielewskiego.

1842 Wspomnienia Żmudzi. Wilno: Naklad i druk T. Glücksberga.

1846 Litwa pod względem starożytnych zabytków, obyczajów i zwyczajów. Wilno: Rafalowicz.

Kynas, Kazys Arūnas

2005 Molètu krašto kalviškoji kryždirbystè XIX-XXa. pabaiga. Molètai: Molètų krašto muziejus.

Kontrimas, Česlovas

1991 Lietuvos geležiniai kryžiai. Vilnius: Mintis.

Krzywda-Polkowski, Franciszek

1909 Krzyźe na Litwie. Materyaty Wydawnictwo towarzystwa „Polska sztuka stosowana“ w Krakowie 12. 
Laučkaitè-Surgailiené, Laima (ed.)

2003 Geležiniai kryžiai Utenos kraštotyros muziejuje: katalogas. Vilnius: Sapnų sala.

Miliauskiené, Marijona (ed.)

2005 Mažosios architektūros paminklu geležinès viršūnès ir kryžiai: katalogas. Rokiškis: Rokiškio krašto muziejus.

Mockutè, Skaistè (ed.)

2003 Geležiniu kulto ir memorialiniu paminklu viršüniu rinkinys Šiauliu „Aušros“ muziejuje: katalogas. Šiauliai: Šiaulių „Aušros“ muziejus.

Perkowski, Juzef

1929a O krzyźach i kapliczkach przydrożnych żmudskich i polskich. Dzień Koweński 130: 2-3; 131: $2-3 ; 134: 2-3 ; 135: 2-3 ; 136: 2-3 ; 140: 2-3 ; 141: 3 ; 146: 2-3 ; 147$ : 2-3.

1929b O źmudzkich figurkach ludowych Matki Boskiej i Chrystusa „Smutkelisa“. Dzień Kowienski 195: 2-3; 196: 2-3; 199: 2-3; 200: 2-3; 201:. 2-3; 204: 2-3; 205: 2-3.

Petruliené, Daliutè

2003 Joniškio krašto sakralinès kalvystès paminklai. Šiauliai: K. J. Vasiliausko įm.

Petrulis, Juozas

1943 Vieno liaudies menininko kūrybos bruožai. Gimtasai kraštas 31: 172-176.

1960 Liaudies skulptorius iš Gruzdžių. Leninietis 7: 3.

1963 Jeronimas Rumša. In: Abramavičius, Vladas et al. (eds.), Kraštotyra. Vilnius: LTSR Kraštotyros draugija, 106-108.

$1964 a$ Kraštotyrininkų „prikeltas“. In: Abramavičius, Vladas et al. (eds.), Kraštotyra. Vilnius: LTSR Kraštotyros draugija, 202-205.

1964b Nirtaičių „keistuolis“. Meno saviveikla 11: 16.

1965 Senieji liaudies menininkai. Mokslas ir gyvenimas 10: 32-34; 11: 31-34.

1968 Nemuno kranto dievdirbis. Muziejai ir paminklai. Vilnius: Vaizdas, 123-124.

1986 Medžio drožèjai. In: Vèlius, Norbertas et al. (eds.), Upytè. Vilnius: Mintis, 83-86.

Petrulis, Juozas and Žemaitytè, Zita

1966a Trys dievdirbių kartos. Kultūros barai 4: 60-63.

1966b Tūkstančio skulptūrų meistras. Kultūros barai 12: 21-24.

1969 Skulptorius iš Rozalimo. Kultüros barai 3: 58-62.

1971 Šimtametis skulptorius. Kultūros barai 2: 50-56.

Počiulpaite, Alè

2008 Tradicinių mediniu paminklų kopijos ir jų aktualizavimas dabarties liaudies kultūroje. In: Počiulpaitè, Alè (ed.), Kryždirbystès fenomenas liaudies kultūroje. Vilnius: Lietuvos liaudies kultūros centras, 172-192.

Połujański, Aleksander

1859 Wędrówki po gubernji augustowskiej. Warszawa: Drukarnia gazety Codziennej.

Römer, Alfred

1860 Ubiory włościan i krzyże na Żmudzi. Tygodnik Illustrowany 40: 364-365.

Rūkštelè, Antanas

1929 Lietuviu tautodailè. Kaunas: Lietuvių dailès draugija.

1931 Lietuvių liaudies kryžiai. Naujoji Romuva 12: 287-288.

1941 Lietuviškų kryžių atsiradimas ir jų plitimo priežastys. I laisvę 95: 3-4.

Spudyte, Elvyra (ed.)

2005 Mažosios architektūros paminklu viršūnès ir antkapiu kryžiai. Rinkinio katalogas. Telšiai: Spaudos lankas.

Stravinskas, Antanas and Sakalauskas, Mečislovas, (eds.)

1992 Lietuvių liaudies menas. Mažoji architektüra. Kn. 3. Vilnius: Vaga. 
Szukiewicz, Wandalin

1903 Krzyźe zdobne w guberniji Wilenskiej. Wisla 17: 700-706.

Šakienè, Jūratė (ed.)

2008 Mažosios architektūros paminklu geležinès viršūnès ir antkapiniai kryžiai. Katalogas. Ukmergè: Valdo leidykla.

Šešelgis, Kazys (ed.)

1990 Lietuviu liaudies menas. Mažoji architektūra. Kn. 2. Vilnius: Vaga.

Šimonis, Kazys

1923a Lietuvių kryžiai. Skaitymai 24: 155-163.

1923b Vincas Svirskis ir jo kryžiai. Gairès 5: 309-311.

Tumenas, Vytautas

2009 Zarasų krašto medžio drožèjai: kultūrinès tapatybès bruožai. In: Vaitkevičienè Ilona (ed.), Zarasu krašto gyvieji tradiciniai amatai. D. 1. Zarasai: Zarasų krašto muziejus, 42-59.

UNESCO 2001 http://www.lietuva.lt/en/tourism/what_to_see/unesco_heritage

Urboniené, Skaidrè

1997 Šventųjų moterų vaizdavimas lietuvių liaudies tradicinèje skulptūroje. Lietuvių katalikų mokslo akademijos metraštis 11: 225-235.

2002 Mažosios architektūros paminklų geležinès viršūnès. Antkapiniai geležiniai kryžiai: rinkinio katalogas. In: Urboniené, Skaidrè (ed.), Etnografija: metraštis. T. 12. Vilnius: Lietuvos nacionalinis muziejus.

2009 Sacral Folk Sculpture in the Rural Culture of Lithuania (the 2nd half of the 19th c. - the 1st half of the 20th c.): Summary of Doctoral Dissertation. Vilnius: Vilnius Art Academy.

Varnas, Adomas

1925 Lietuvių kryžiai. Baras 5: 81-83.

Vorobjovas, Mikalojus

1939 Mūsų dievukai ir jų vertinimas. Lietuvos aidas 194: 206

Zabielienè, Aušra

2010 Folkloro ansambliai dabartineje Lietuvoje: etnologinis aspektas. Vilnius: Firidas.

Zabulytè, Jolanta

2007 Lithuanian Wooden Crosses 19 ${ }^{\text {th }}$-mid 20 ${ }^{\text {th }} \mathrm{c}$. in the Context of World Traditions: Summary of Doctoral Dissertation. Vilnius: Vilnius Art Academy.

Žemaitytè, Zita

1970 Ukmergès rajono liaudies memorialiniai paminklai ir jų kūrèjai. Muziejai ir paminklai. Vilnius: Vaizdas, 88-98.

1981 Senoji Žemaitijos liaudies skulptūra ir jos meistrai. In: Umbrasas, Jonas et al. (eds.), Dailetyra. Vilnius: Vaga, 246-258.

\section{RAZMERJE MED RAZISKOVALCEM IN IZVAJALCEM PRI RITUALIH REZLJANJA KRIŽEV V LITVI}

Članek obravnava razmerje med raziskovalci in ustvarjalci (rezbarji) v Litvi od 19. stoletja do danes. Prve omembe lesenih votivnih znamenj so iz srede 19. stoletja, prve raziskave pa iz začetka 20. stoletja: lesena znamenja in verski kipi so postali ena najbolj priljubljenih tem za litvanske znanstvenike in lokalne etnografe. 
Ob prelomu stoletja in v prvi polovici 20. stoletja so raziskovalci večinoma le zbirali in dokumentirali rezljanje križev. Za enostranski odnos je bilo značilno, da so bili rezbarji sami eksperti za izročilo, raziskovalci pa so se v stiku z njimi poučili o tehnikah in stilih rezljanja; njihovi medsebojni odnosi so bili omejeni na pisanje biografij in fotografiranje. Tudi v sovjetskih časih je bil odnos med raziskovalci in rezbarji enostranski; raziskovalci so dokumentirali tradicijo, spraševali stare mojstre in zbirali gradivo.

Intenzivnejsi stik med raziskovalci in rezbarji je značilen za čas od leta 2001 naprej, ko je bilo rezljanje križev sprejeto na Unescov seznam nesnovne kulturne dediščine. Danes se rezbarji opirajo na znanje raziskovalcev; $v$ stiku z njimi obnavljajo in ohranjajo živo izročilo rezljanja križev. Raziskovalec je odločilen pri procesu izdelave kopij; $v$ drugih primerih pa najpomembnejši ustvarjalec sam, raziskovalec pa ima vlogo svetovalca.

Nova generacija umetnikov ne pozna tradicije, zato se mora opirati na raziskovalca. Včasih so se izdelovalci križev učili drug od drugega, saj je mojster skrivnosti rezljanja predal sinu oziroma vnuku. Danes takšne kontinuitete ni več. Rezbarji, pogosto mladi, potrebujejo ne le tehnološko znanje (tega pridobijo $v$ kreativnih taborih in rezbarskih šlah), temvec tudi znanje tradicije rezljanja-oblike križev in drugih znamenj, oblikovne posebnosti, teme kipov in še posebej regionalne značilnosti. Sodobni raziskovalec je tako pri poustvarjanju izročila predvsem svetovalec. Varovanje živega izročila rezljanja križev je danes brez (neposredne ali posredne) komunikacije med ustvarjalcem (rezbarjem) in raziskovalcem nemogoče.

Dr. Skaidre Urboniene, Lithuanian Institute of History, Šilo str. 29-18, Vilnius LT-10317, Lithuania, skaidreu@gmail.com 